FEDERAL RESERVE BANK OF SAN FRANCISCO

WORKING PAPER SERIES

\title{
Foreign Bank Lending and Bond Underwriting in Japan During the Lost Decade
}

\author{
Jose A. Lopez \\ Federal Reserve Bank of San Francisco \\ Mark M. Spiegel \\ Federal Reserve Bank of San Francisco
}

November 2006

Working Paper 2006-45

http://www.frbsf.org/publications/economics/papers/2006/wp06-45bk.pdf

\begin{abstract}
The views in this paper are solely the responsibility of the authors and should not be interpreted as reflecting the views of the Federal Reserve Bank of San Francisco or the Board of Governors of the Federal Reserve System. This paper was produced under the auspices for the Center for Pacific Basin Studies within the Economic Research Department of the Federal Reserve Bank of San Francisco.
\end{abstract}




\title{
Foreign Bank Lending and Bond Underwriting in Japan During the Lost Decade
}

\author{
Jose A. Lopez \\ and \\ Mark M. Spiegel* \\ Federal Reserve Bank of San Francisco
}

\begin{abstract}
We examine foreign intermediation activity in Japan during the so-called "lost decade" of the 1990s, contrasting the behavior of lending by foreign commercial banks and underwriting activity by foreign investment banks over that period. Foreign bank lending is shown to be sensitive to domestic Japanese conditions, particularly Japanese interest rates, more so than their domestic Japanese bank counterparts. During the 1990s, foreign bank lending in Japan fell, both in overall numbers and as a share of total lending. However, there was marked growth in foreign underwriting activity in the international yen-denominated bond sector. A key factor in the disparity between these activities is their different clienteles: While foreign banks in Japan lent primarily to domestic borrowers, international yen-denominated bond issuers were primarily foreign entities with yen funding needs or opportunities for profitable swaps. Indeed, low interest rates that discouraged lending activity in Japan by foreign banks directly encouraged foreign underwriting activity tied to the so-called "carry trades." Regulatory reforms, particularly the "Big Bang" reforms of the 1990s, also play a large role in the growth of foreign underwriting activity over our sample period.
\end{abstract}

\section{J.E.L. Classification: F34, G21, G24}

Keywords: Foreign banking, underwriting, samurai bonds

*Corresponding authors, Economic Research, Federal Reserve Bank of San Francisco, 101 Market Street, San Francisco, CA 94105. Christopher Candelaria and Elizabeth Kite provided excellent research assistance. This paper was prepared for the 2006 APEA conference proceedings. The views expressed are solely those of the authors and do not necessarily reflect those of the Federal Reserve Bank of San Francisco or the Federal Reserve Board of Governors. 


\section{Introduction}

During the 1980s, the Japanese financial markets grew dramatically in scale and importance and clearly established Tokyo as a world financial center. Many foreign financial institutions began to establish or greatly expand their presence in these markets. This paper examines the subsequent path of foreign intermediation activity during the socalled "lost decade" of Japan in the 1990s. We examine both lending activity by foreign commercial banks in Japan and underwriting activity in the international yendenominated bond sectors by foreign firms during this period.

At a first pass, it may seem that the connection between these two types of intermediation activities is tenuous, as the act of originating a loan and carrying it on your balance sheet is quite distinct from that of bond underwriting, where the intermediaries attempt to place the debt securities with other investors. However, financial intermediation in all of its forms involves the acquisition of knowledge. While bond underwriters do not directly carry much of the risk associated with their borrowers on their balance sheets, they do carry exposure to the reputation effects of the outcomes of the bonds that they underwrite. Because of this, bond underwriting also involves the costly monitoring of the expected quality of bond issues.

Intermediation takes on special characteristics when the financial intermediary is operating in a foreign market. A potentially important reason is that special regulatory restrictions are often placed on foreign firms. Foreign financial intermediaries also often possess information sets that differ from their domestic competitors, both regarding the prospects of potential borrowers as well as access to investors who desire to take on a certain type of exposure. Access to different information sets implies that foreign 
financial intermediaries may behave differently than their domestic counterparts, even in environments where they stand on an equal regulatory footing. Moreover, the ability of foreign firms to raise lending capital may be exposed to different shocks than those of domestic firms. For example, Peek and Rosengren (2000) demonstrate that foreign bank lending activity is likely to be sensitive to home country conditions. In particular, they show that Japanese bank lending in the United States contracted during the Japanese economic downturn.

In this paper, we examine the impact of domestic economic conditions on foreign intermediation activity. We concentrate on the same episode as that examined by Peek and Rosengren -- the Japanese economic boom of the 1980s and subsequent downturn after the collapse of the asset price bubble in 1992 -- but ask how it affected the behavior of foreign intermediaries operating in Japan. For foreign investment banks, the Japanese downturn implied deteriorated demand conditions by borrowers, but also deteriorated the financial strength of potential domestic competitors.

The net impact on intermediation activity of this shock would then be likely to depend on the relative importance of these two impacts. In the case of lending by foreign banks, we would expect to see the first impact, the downturn in domestic conditions, dominate. On the other hand, in the case of underwriting activity, especially in the international yen-denominated markets, we would expect the second impact, the increase in the potential competitive advantage of foreign underwriters, to have the dominant effect as financing was extended to borrowers outside Japan.

We first examine the pattern of lending activity by foreign banks in Japan. We find that the share of foreign bank lending fell sharply subsequent to end of the asset 
price bubble in the beginning of the 1990s, and again subsequent to the launch of the "quantitative easing" policy by the Bank of Japan in 2001. This finding seems logical as the decline in funding demand would be paramount for foreign banks making loans that they intended to keep on their books.

While our results may appear to support those who claim that foreign banks exacerbate the volatility of credit extension, that is not necessarily the case. We do confirm that foreign bank lending in Japan exhibited more volatility, as measured by Sharpe ratios, than lending by domestic banks over the "lost decade" period. However, as foreign bank lending was imperfectly correlated with domestic bank lending in Japan, we find that the overall volatility of total bank lending was lower than that of the domestic bank lending time series on its own.

We then turn to bond underwriting as another major channel of financial intermediation. While foreign firms did begin their underwriting activities in the domestic Japanese market by the mid-1990s, we examine their international yendenominated bond-underwriting activities, such as those in the euro-yen and "samurai" bond markets, where regulation played a much smaller role. These underwriting activities do not constitute foreign lending to Japan per se, since the bonds are primarily designated for lending to foreign borrowers. Nevertheless, they do constitute foreign intermediation activity in the Japanese financial markets, as foreign firms bring to bear their expertise both in locating potential investors and in assessing borrower quality.

Issuance of these bonds exhibited an upturn in 2000 and into the quantitative easing period for various reasons, such as the growing spreads between Japanese and emerging-market country interest rates contributing to "carry trade" intermediation 
towards those countries. We demonstrate that foreign investment banks played a large role in underwriting this activity, and gained market share over the course of the so-called lost decade. While other changes, such as regulatory innovations, also contributed to the increase in foreign participation in Japanese underwriting activity, we argue that the increased share of foreign underwriting was also encouraged by the financial difficulties faced by domestic competitors during this period.

Our analysis therefore indicates that foreign financial activity in Japan responded to changes in the Japanese environment differently, depending on the nature of the activity. In the case of formal bank lending, the deterioration in local Japanese borrowing capacity and the increase in the interest rate differential between the United States and Japan in the wake of "quantitative easing" efforts by the Bank of Japan diminished the abundance of profitable lending opportunities. In contrast, these same interest rate movements encouraged foreign financial market participation in the international yendenominated bond underwriting activity, as foreign underwriting efforts eased foreign access to low Japanese lending rates, while the deterioration in local borrowing conditions had little impact.

The remainder of this paper is organized into five sections. The next section reviews the literature on foreign intermediation, which is dominated by analyses of the impact of foreign banks on the domestic banking sector. The following section examines the experience of foreign banks in Japan during the lost decade. Section 4 examines the experience of foreign underwriters in international yen-denominated bond markets, and Section 5 concludes. 


\section{Literature on foreign intermediation activity}

The literature on the impact of foreign competitors on the domestic financial sector has primarily stressed the case of sophisticated and large developed-country foreign banks operating in emerging-market economies. A primary issue in this literature is whether or not the presence of foreign banks enhances the stability of the domestic financial system. Loosely, the argument in favor of this contention is that foreign banks can rely on home markets for credit during local downturns, while their domestic counterparts will find their credit sources more constrained. The primary argument on the other side stresses the fact that foreign banks are likely to be less committed to operations in the emerging market economy, and therefore will reduce their activity more abruptly during downturns, exacerbating the volatility of the supply of credit. ${ }^{1}$

Overall, the evidence appears to be mixed. Galindo et al. (2004) develop a model where foreign banks are less sensitive to local liquidity shocks. However, they find empirically that foreign banks exhibit a characteristic they term "fickleness," in that welldiversified foreign banks are prone to respond quickly and decisively to changes in the relative attractiveness of opportunities in a foreign host country.

Arena et al. (2006) find that foreign banks are less sensitive to local monetary conditions. They also find that the lending and deposit rates offered by foreign banks tend to be modestly smoother during periods of financial distress, although the differences are not statistically significant. Their findings therefore do not support the contention that foreign banks exacerbate the volatility of domestic credit conditions, although neither do they provide evidence that foreign banks have a significant stabilizing impact.

\footnotetext{
${ }^{1}$ Another potential implication of foreign bank entry is on the competitiveness of the domestic banking sector; see Claessens and Glaessner (1998) for example.
} 
Goldberg (2002) looks at the volatility of U.S. bank claims on foreign countries. She finds that U.S. foreign claims seem to respond to source country conditions. However, she does not find that foreign claims of U.S. banks are correlated with foreign real interest rates, and overall, the economic importance of local macroeconomic conditions on U.S. bank lending is found to be minimal.

Other studies do not look directly at bank lending patterns, but instead examine the implications of domestic financial policies. Claessens and Glaessner (1998) find that costs of financial services in eight developing Asian economies are decreasing in those countries' levels of financial openness. However, they argue that a subset of foreign banks can overcome this disadvantage because of specialized knowledge of the host country in question. For example, a foreign bank may have specialized knowledge of a former colony of its country of origin. They find that this subset of foreign banks do not exhibit an efficiency disadvantage relative to domestic banks. Berger, et al. (2000) find that foreign institutions are generally less efficient than their domestic counterparts.

Despite the fact that the bulk of international lending takes place between developed nations, there is less evidence concerning the patterns of foreign lending in developed countries. In a series of papers, Peek and Rosengren $(1997,2000)$ have documented supply shocks to the extension of credit by Japanese banks in the United States subsequent to the sharp decline in equity values experienced in that nation. Peek and Rosengren (1997) find decreased lending by U.S. branches of Japanese banks subsequent to these equity declines, while Peek and Rosengren (2000) finds a negative impact of this decreased Japanese bank activity on real activity in the United States. 
This paper examines the opposite question, namely the degree to which foreign bank activity in Japan responded to host country conditions. While there is an extensive literature on this question for emerging market economies, discussed in part above, the literature for developed countries, which constitute the destination for the bulk of foreign lending flows, is much more sparse. One exception is Goldberg (2006) who examines the pattern of U.S. bank lending in Europe. Goldberg finds weak evidence that U.S. bank flows to Europe are procyclical, with U.S. bank loans to Europe increasing in European GDP and decreasing in European interest rates, although the first result is not statistically significant.

Since bank lending is typically the main external funding source for borrowers, the term "financial intermediation" almost always refers to banking activities. ${ }^{2}$ However, capital markets activities, especially the issuance of financial securities, also provide borrowers with external financing, although with important differences in such areas as monitoring and corporate governance.

The international bond market in a given currency is commonly divided into three segments -- domestic bonds, foreign bonds, and Eurobonds - separated mainly by homecountry regulations. Domestic bonds are issued by mainly domestic entities, in the domestic currency, under domestic regulations, and sold predominantly to domestic residents. Foreign bonds are issued by foreign borrowers within the domestic market of the currency of denomination and again under domestic regulation, which can be quite different than that for domestic bonds. Finally, Eurobonds are issued mainly outside of domestic regulations and are issued by borrowers of various nationalities with the assistance of international syndicates of bond underwriters. While these bonds may be

\footnotetext{
${ }^{2}$ See Gorton and Winton (2003) for an overview of bank-like financial intermediation.
} 
purchased by domestic investors under domestic regulations, a significant percentage of the bonds are purchased by investors domiciled in other countries.

The extant literature on the impact of foreign competitors on bond underwriting by a currency's domestic institutions is quite small and typically limited to specific episodes. Balder et al. (1991) examined Eurobond underwriting in the late 1980s and found that underwriters had a competitive advantage in issues denominated in their home currency. Similar results were found by McCauley and White (1997) and McCauley (1999). However, Kollo (2005) found that this advantage had been in decline since 1993.

A few studies have examined the effect of the introduction of the euro and the concurrent retiring of the various European national currencies on the Eurobond market. Studies by Galati and Tsatsaronis (2003), Santos and Tsatsaronis (2003), and Kollo (2005) found increased competition in Eurozone underwriting markets. However, the studies disagree mildly on the source of the competition with the first two studies assigning greater weight to competition by non-European, particularly American, underwriters, while the latter study argues that competition in general increased.

Focusing on Japan, several papers have examined the impact of increased competition in the domestic bond markets arising, not from foreign firms, but from the securities subsidiaries of Japanese commercial banks. In April 1993, Japan's Financial System Reform Act removed most barriers between commercial and investment banking, thus allowing commercial banks to underwrite securities. As reported in Hamao and Hoshi (2000), their share of bond issues as lead managers rose from $9 \%$ in the first quarter of 1994 to $42 \%$ in the first quarter of 1995 and to $85 \%$ by the end of 1997 . With respect to the percentage of funds raised, the values went from $7 \%$ to $34 \%$ to $82 \%$, respectively. 
Hamao and Hoshi (2000) argue that the aggressive strategies used by these new underwriters were successful in capturing market share, even in light of the potential conflicts of interest arising from banking ties between issuers and the subsidiaries' parent firms. Takaoka and McKenzie (2004) document that the entry of these competitors lowered underwriting commissions. Yasuda (2005) shows that borrowers with lending relationships were offered even lower underwriting fees.

However, the viability of this strategy was questioned, as shown by McKenzie and Takaoka (2006), who demonstrate that borrowers switched away from using these new underwriters on their subsequent bond issues. In fact, as documented by Hamao and Hoshi (2000), many securities subsidiaries were merged or liquidated a few years after their creation. In this paper, we focus on foreign firms' entry into the international yendenominated sectors, since foreign firms have not advanced as much in their entry into the domestic bond market.

\section{Foreign bank lending in Japan during the lost decade}

This section examines the pattern of foreign bank activity in Japan from 1983 through 2006. Over this period, Japan experienced an economic boom, followed by a collapse in equity prices and stagnant economic activity for the following ten years, a period commonly referred to as the "lost decade." More recently, economic activity in Japan has rebounded significantly, sufficiently so that the Bank of Japan has decided to

move off of the so-called "quantitative easing" policy it had adopted in 2001 to stimulate bank lending, whereby it flooded Japanese banks with excess reserves in the hope that doing so would encourage additional credit creation. 
We concentrate on two questions: First, to what extent do foreign bank lending levels in Japan respond to domestic conditions, i.e. how cyclical is foreign bank lending in Japan? Second, how does the presence of foreign lending affect the overall volatility of credit conditions in Japan?

Figure 1 depicts the total and share of foreign bank lending in Japan over our 24 year sample period. The data demonstrate that foreign lending levels appear to be procyclical to some extent, although the share of foreign bank lending in the overall Japanese bank lending package has remained surprisingly stable in the range of 1.5 to 3 percent of overall Japanese bank lending. Troughs in the share of foreign lending occurred after the equity market crash in 1995 and at the height of the quantitative easing period around 2005 in which Japanese commercial banks were flooded with excess reserves by the Bank of Japan to encourage lending. These troughs appear to correspond to poor economic fundamentals in the first case, and low domestic interest rates in the latter one. Still, there are glaring exceptions. A trough in the share of foreign bank lending occurred in 1990, during the height of the Japanese boom. It is therefore unclear how cyclical foreign lending is relative to domestic lending.

While it represents a modest share of overall Japanese lending, foreign bank lending in Japan has been extremely volatile. Figure 2 depicts annual year-on-year growth in foreign and domestic lending in percentage terms. It is clear that in percentage terms, foreign lending has been much more volatile than domestic lending over our sample period. Moreover, if one looks carefully, it is clear that growth in foreign bank lending is positively correlated to growth in domestic bank lending. Over our complete sample, the correlation coefficient is 0.30 . 
To formally gauge the impact of foreign lending on the volatility of bank credit in Japan, we calculated Sharpe ratios for domestic and foreign lending from the beginning of 1983 through the second quarter of 2006, defined as the sample average divided by the sample standard deviation. We obtain a Sharpe ratio of 4.46 for foreign bank lending over the sample period, but one of 4.78 for domestic bank lending, implying that foreign lending was indeed more volatile than domestic lending over the period. Perhaps more surprisingly, because foreign lending was positively correlated with domestic lending, the Sharpe ratio for domestic lending alone was modestly greater than that for domestic plus foreign lending, which came in at 4.80 . This suggests that while the univariate foreign lending series was more volatile than its domestic lending counterpart, it appears to have modestly reduced the volatility of credit extension over this period as it was imperfectly correlated with domestic lending.

Some caveats should be mentioned concerning this result. First, it is likely that in the absence of the foreign banks, much of the lending activity that they conducted would have been undertaken by domestically chartered banks, so the comparison is not particularly apt. Second, for some potential clients, a significant portion of lending by foreign banks in Japan is engaged in servicing subsidiaries of home-country firms. As such, the intermediation services by foreign and domestic Japanese banks are substitutable only to a limited degree.

We next examine parametric evidence concerning the determinants of foreign and domestic bank lending in Japan over our sample period. Our basic model specifies the lending decision as a response to the perceived relative opportunities for profits in Japanese bank lending. As such, we condition on both Japanese and U.S. interest rates, 
where the latter is taken as indicative of the "world" rate of interest, or the rates of return available for lending abroad, as well as measures of local and foreign economic conditions. Japanese economic conditions are proxied for by the growth of GDP measured in log differences. As a measure of home country conditions for the foreign banks, we take the growth in the total level of GDP for the original 20 OECD countries net of Japan, again measured in $\log$ differences. ${ }^{3}$

Our base specification follows Goldberg $(2002,2006)$ in assessing the relative sensitivity of foreign and domestic Japanese banks to local and home economic conditions. We estimate:

$$
\mathrm{L}_{\mathrm{t}}=\alpha+\beta_{1} \mathrm{t}+\beta_{2} \log \left(\mathrm{r}_{\mathrm{t}}^{\mathrm{J}}\right)+\beta_{3} \log \left(\mathrm{r}_{\mathrm{t}}^{\mathrm{US}}\right)+\beta_{4} \mathrm{gGDP}_{\mathrm{t}}^{\mathrm{J}}+\beta_{5} \mathrm{gGDP}_{\mathrm{t}}^{\mathrm{CC}}+\beta_{6} \mathrm{BOOM}_{\mathrm{t}}+\varepsilon_{\mathrm{t}}
$$

where $t$ represents a linear time trend; $r_{t}^{J}$ is the 3 -month Japanese interest rate at time $t$, $r_{t}^{U S}$ is the 3-month U.S. interest rate at time $t, g G D P_{t}^{J}$ represents real GDP growth in Japan at time $t, g G D P_{t}^{C C}$ represents real GDP growth in potential creditor countries at time $t$, measured as the percentage growth in the sum of the 20 original OECD countries, excluding Greece, Ireland, and Japan itself; $B O O M_{t}$ is a zero-one dummy identifying the boom portion of the sample, with value one for all year prior to 1992 and value zero afterwards; and $\varepsilon_{t}$ is an i.i.d. disturbance term. We estimate the specification using ordinary least squares with White's heteroskedasticity correction.

Our results are shown in Table 2. It can be seen that lending by both foreign and Japanese banks appears to respond to differences in Japanese and world interest rates with the proper sign. Both with and without the inclusion of a linear time trend, foreign

\footnotetext{
${ }^{3}$ Due to data limitations, Greece and Ireland are also excluded.
} 
and domestic bank lending in Japan is increasing in Japanese interest rates and decreasing in U.S. interest rates, usually at statistically significant levels. The exception is the sensitivity of Japanese bank lending to U.S. interest rates, which is unsurprisingly insignificant. It can also be seen that foreign bank lending in Japan seems to be more sensitive to Japanese interest rates than domestic bank lending, confirming the results above that foreign bank lending appears to be more volatile.

The results for GDP growth, both in Japan and abroad, are weaker. We do obtain the expected result that foreign bank lending in Japan is measurably declining in growth in creditor countries' home markets, at a 5\% confidence level when the linear time trend is included, and at a $10 \%$ confidence level when the linear time trend is excluded. The impact on Japanese bank lending has the same sign, but the coefficient estimates are smaller than those on the foreign banks and are statistically insignificant. The evidence therefore suggests that foreign bank lending in Japan is more sensitive to external conditions than domestic bank lending.

Concerning domestic economic conditions, we obtain an unexpected negative coefficient for both domestic and foreign bank lending in Japan, with the point estimates for foreign bank lending again exhibiting greater sensitivity. This result is surprising, as one would expect greater lending during good times. The result may be indicative of a demand effect, where in good times borrowing firms have access to alternative financing sources, such as commercial paper. Alternatively, it could reflect the easy monetary policy that pervaded Japan during the latter 1990s, although the latter explanation conflicts with our results for Japanese interest rates above. We similarly obtained a 
negative and significant coefficient on the $B O O M_{t}$ dummy, suggesting that bank lending was greater during the post-boom era.

To mitigate estimation problems stemming from potential unit root issues in our time series, we next differenced the data and used the following specification

$$
\Delta L_{t}=\beta_{1}+\beta_{2} \Delta \log \left(r_{t}^{J}\right)+\beta_{3} \Delta \log \left(r_{t}^{U S}\right)+\beta_{4} \Delta g G D P_{t}^{J}+\beta_{5} \Delta g G D P_{t}^{C C}+\beta_{6} B O O M_{t}+v_{t} \cdot(2)
$$

Note that the constant term would now be interpreted as $\beta_{1}$, the coefficient estimate on the linear time trend. We also ran the specification with and without the $B O O M_{t}$ dummy, which drops out after first-differencing the specification in equation (1), but which we also allowed to enter to capture the possibility of a shift in the linear growth trend around the end of the boom period.

Our results are shown in Table 3. It can again be seen that both foreign and domestic banks respond to Japanese interest rates, with changes in foreign bank lending being much more responsive than their domestic counterparts. Looking at U.S. interest rates, we again see that foreign bank lending is sensitive to these rates at statistically significant levels. The results for Japanese banks are mixed, as U.S. rates enter insignificantly without the inclusion of the $B O O M_{t}$ dummy, but significantly with the incorrect positive sign with the dummy variable included. In either specification, the coefficients on foreign bank lending are substantially more negative, suggesting as expected that foreign lending rates in Japan are more sensitive to home country conditions than domestic bank lending rates are to foreign conditions.

For the remaining variables, we fail to find any statistically significant relationship between changes in GDP growth and changes in lending rates for either 
domestic or foreign bank lending, while the $B O O M_{t}$ dummy appears to reverse the sign on the constant term. Recall that in our changes specification, this term corresponds to the linear trend for lending levels.

In summary, our data suggest that foreign bank lending levels are generally more sensitive to both domestic and foreign interest rates, as would be expected. These results are consistent with our earlier finding that foreign bank lending in Japan during this period was more volatile than domestic bank lending. However, it should be stressed that this does not necessarily imply that the presence of foreign banks exacerbates the overall volatility of bank activity in Japan, as foreign and domestic lending rates are imperfectly correlated. Indeed, our earlier results demonstrate that the time series inclusive of foreign bank lending is modestly less volatile than the time series of domestic bank lending alone over our sample period.

\section{Foreign activity in yen-denominated bonds}

In this section, we examine the role that foreign securities firms played in the international yen-denominated bond underwriting during the 1990s. In Japan, the foreign bond market is known as the "samurai" bond market and dates back to a 1970 bond issue by the Asian Development Bank. The market was controlled quite closely by the Ministry of Finance using regulations targeted at the eligibility of issuers, underwriters and investors; see Hoschika (2005) for further details. Most of these controls were not fully removed until the broader financial market deregulation of 1998. The Euroyen bond market, which dates back to at least 1977, was also subject to related controls, as detailed in Hoshi and Kashyap (1999), that were also removed in the late 1990s. 
Figure 3 presents nominal issuance in the samurai and Euroyen bond markets from 1992 through 2005, based on annual summary data from the International Financing Review. ${ }^{4}$ Issuance in these two markets has clearly followed the overall pattern of the Japanese banking crisis. Samurai bond issuance rose up through 1996, but then dropped to a low in 1998. Subsequent issuance has been driven primarily by the level of yen interest rates and yen-related swap rates. According to Claessens et al. (2000), yendenominated Eurobonds over the period from 1980-2000 accounted for 13\% of issues and about $8.25 \%$ of nominal issuance values. Issuance in the Euroyen market peaked in 1994 before dropping sharply to a low in 1998. Again, subsequent issuance, except for 2000 when many U.S. corporates issued debt, has been in line with the level of yen interest rates and yen-related swap rates.

Bond underwriting in the international yen sector follows the general procedures used in the Eurobond markets; see Claes et al. (2002) for a more detailed description. The financial firm that is the principal player in a bond underwriting transaction is known as the bookrunner. The bookrunner initiates the transaction with the borrower and is responsible for organizing the underwriting syndicate (if one is used), pricing the bond and placing of the issue, either directly with investors or in the primary market. ${ }^{5}$ The former are known as "bought" deals, where the underwriting syndicate purchases the entire issue and distributes it to their clients. A reasonably large amount of Eurobond issuance is "bought" deals. The latter requires the bookrunner to make a market in the bond in order to support initial trading and placement at the specified price.

\footnotetext{
${ }^{4}$ The International Financing Review is a weekly publication covering the international bond markets.

${ }^{5}$ For $91 \%$ of Eurobonds, the issue is coordinated by one bookrunner.
} 
Either way, the bookrunner specifically and the syndicate in general takes on substantial risk since they have taken the bond issue onto their own books for a period of time. This activity is much like a bank placing a loan onto its books, however the key difference is that bond underwriters hope to quickly remove the loan from their books and place it with investors. A common measure of compensation is the underwriter spread, defined as the gross fees charged by the underwriter as a percent of the issuance size. It is a measure of the underwriter's compensation for absorbing risk in the distribution of securities. Of course, default risk is also a component of that compensation, but the nature of the Eurobond market is such that issuers generally carry a higher credit profile to overcome the information asymmetry barriers of issuing into this market. For example, in the Kollo and Sharpe (2002) study of financial firms, the sample contained less than one percent of issues below investment grade.

Overall, underwriting activity in the Eurobond markets are very competitive, with few barriers to entry and a low level of underwriter concentration. For yen-denominated bonds, the Eurobond markets are definitely much less concentrated than the domestic market, where the first foreign underwritten issue was not recorded until 1995. While the international yen bond markets remained concentrated within the hands of Japanese underwriters for some time, the degree of concentration has decreased much more rapidly than the domestic market.

In terms of financial intermediation, the bookrunner brings a variety of pieces together that are quite informationally intensive. In particular, the bookrunner must convince a borrower to issue in a particular sector and currency denomination. He must have an investor clientele that will be willing to purchase the bond issue. He is expected 
to construct an underwriting syndicate, if needed, to place the issue. He must be capable of supporting the bond issue in the primary market. Finally, since on the order of $70 \%$ of Eurobond issuance is said to be swap-driven, as reported by Claes et al. (2005), the bookrunner must be able to manage this component of the financing in an effective manner.

Domestic underwriters might have a comparative advantage in some dimensions, such as understanding movements in domestic economic fundamentals and/or from superior access to investors wishing to invest in the domestic currency. They might also be protected from competition from foreign underwriters by national regulation, as was the case in Japan, where the securities subsidiaries of Japanese banks were not allowed to underwrite bonds until 1992 and all restrictions on underwriters were removed by 1998 .

However, foreign firms may possess different skills and information sets that could allow them to compete in these markets. For example, a foreign firm could bring to market its own roster of domestic markets or expand its services to domestic borrowers with whom they already enjoy overseas relationships. A foreign firm could use its own roster of domestic and international investors to place the bonds. Similarly, the foreign firm could be better able to execute the underlying currency swaps, either due to their superior market presence, or to better pricing due to their credit ratings. This might have been particularly true during the late 1990s, when many Japanese financial institutions were experiencing distress. The foreign firm might also be able to introduce a financial innovation that might not be available or familiar to domestic firms, as in the case of the Merrill Lynch introduction of dual currency bonds to the Japanese samurai bond market discussed below. 
To examine the activity of foreign underwriters in the international yen bond markets during the 1990s and early 2000s, we again use data from the IFR data. In particular, we use the league tables for both the samurai and Euroyen markets from 1992 through 2005. The league tables are constructed by assigning the appropriate share of a bond issue to its bookrunner(s). For example, a sole bookrunner receives a $100 \%$ share, whereas two co-bookrunners receive a 50\% share. The bookrunners are then ranked by their total issuance in that market for the year. The IFR publishes the league tables consisting of the top ten bookrunners for each year; see Table 4 for an example of the Euroyen league tables for 1995 and $2005 .^{6}$ Note that in a few cases the top ten bookrunners accounted for nearly 100 percent of issuance in that market sector for that year, but that is typically not the case. While in some cases the percentage underwritten by the top ten bookrunners can fall to the low $80 \%$ 's, we are assuming that the majority of the underwriting activity is being captured by the top ten firms.

We follow Kollo (2005) in estimating underwriters' market shares by using their market shares in the top ten league tables. In general, studies of the U.S. bond market have used one of two primary approaches to measuring underwriting activity. Carter and Manaster (1990) rank underwriters based on their hierarchical bracket positions in public announcements of new issues, while Megginson and Weiss (1991) use underwriter market share in dollar terms. The latter authors found a high positive correlation between the rankings.

\footnotetext{
${ }^{6}$ U.S. studies have used two primary approaches to proxy underwriter reputation: A ranking based on the underwriter's hierarchical bracket position in new issue tombstone announcements [e.g. Carter and Manaster (1990)]; and the market share of the underwriter in dollar terms over a prior period [e.g. Megginson and Weiss (1991)]. As Kollo (2005) finds a high positive correlation between the rankings and a tombstone ranking is not available for the Eurobond market, we use the market share approach."
} 
Figures 4 and 5 present the percentage of issuance in the samurai and Euroyen sectors, respectively, by Japanese and American bookrunners in the top ten league tables for the years 1992 through 2005. Both charts clearly present the declining share of underwriting by Japanese firms in both sectors of the international yen bond market. The decline is most pronounced in the Euroyen sector (see Figure 5), where the share declined from $93 \%$ in 1992 to $30 \%$ in 2005 . The U.S. share rose from $6 \%$ to $35 \%$ during this period. A reason for the relatively smooth decline of the Japanese share is that the Euroyen sector is only lightly regulated. ${ }^{7}$ Hence, competition for underwriting mandates was more open and permitted the foreign firms to use any of their available comparative advantages to full effect.

In contrast, the decline in the Japanese share of the samurai bond underwriting market starts very directly in 1998. Prior to that, Japanese firms underwrote nearly all of these bonds. In fact, the first samurai bond for which a foreign firm was the bookrunner was issued only in 1995. A key reason for this dominance was regulation of the market for both issuers and borrowers. For example, prior to 1993, securities firms affiliated with Japanese banks were prohibited from underwriting any bonds. Also, prior to 1996, the Ministry of Finance had in place credit rating eligibility requirements that prevented low rated and unrated borrowers from issuing in the samurai market. The prohibition on samurai underwriting by foreign bank-affiliated securities firms was removed in 1997 [IFR (1997 )]. It was in 1998 that the U.S. share of samurai bond issuance increased markedly from a few percentage points to 25 percent.

\footnotetext{
${ }^{7}$ For example, as reported in the IFR in December 1993, the Japanese Ministry of Finance lifted the requirement of a 90-day lock-up period for Euroyen issuance by sovereigns, which will lead to more issuance in Eurobonds because these underwriting fees are lower than in Samurai issues.
} 
Our ability to explain the change in underwriting shares by U.S. and foreign securities firms is limited by our lack of data on individual bond issues. However, anecdotal evidence gleaned from weekly IFR reports provide some market-specific insights. Regarding the issue of a foreign firm bringing to market its own roster of domestic and international borrowers, there appears to have been several examples during this period. One example is the increased issuance by U.S. corporations in 2000 due primarily to changes in U.S. accounting rules. Most of these issues had U.S. bookrunners, although often with Japanese firms as equal partners. Similarly, various press accounts of U.S. firms leading underwriting syndicates for Japanese firms cite both their long-term business relationships in the overseas markets and innovative financing structures.

A potentially important informational difference between Japanese and foreign firms is the set of end investors. Of course, securities firms work to establish relationships with various types of institutional investors, but the degree of success in uncertain. The anecdotal evidence weakly supports the notion that Japanese firms may have placed more of their issuance with Japanese investors than foreign firms, but even the Japanese firms are found to place roughly $80 \%$ of their issuance overseas.

Much clearer evidence on the impact of investor information sets arises from the introduction of dual-currency samurai bonds issued by lower quality sovereign borrowers. Dual-currency bonds have their interest and principal payments denominated in different currencies and were introduced to the samurai market by Merrill Lynch in 1996. Aside from the innovation in financing structure, an important innovation with these issues was that they were targeted to retail investors, which was possible after 
deregulation by the Ministry of Finance allowed these retail transactions. While Merrill had some retail clientele in Japan, they were able to market the securities on a larger scale by coordinating their distribution network with those of smaller Japanese brokerage firms. This episode highlights how foreign underwriters can use their knowledge and expertise in alternative funding methods to their advantage.

Finally, the swap driven element of their bond issues seems to provide foreign firms with some advantages in the international yen market for two reasons. First, borrowers with multi-currency relationships with a foreign underwriter would feel comfortable with them in yet another currency. Of course, this element would also be present for Japanese firms with established relationships. More compelling is the development of the "Japan premium" in 1995 and for a few years afterward. Anecdotally, this rise in funding costs hurt Japanese underwriters in their perceived ability to absorb the underwriting risks and hence provide funding at a competitive rate. ${ }^{8}$

In summary, the behavior of foreign securities firms, in particular U.S. firms, in the international yen-denominated bond markets has been impacted by Japanese domestic economic conditions, but seemingly less so than in the domestic banking sector. While issuance has primarily been driven by yen interest rates and swap rates, the participation of foreign firms has been increasing, particularly due to the deregulation of these markets. However, the weakening, and even failure, of Japanese firms also allowed foreign firms to capture market share through acquisition and increased acceptance by borrowers and investors.

\section{Conclusion}

\footnotetext{
${ }^{8}$ For a discussion of the Japan premium, see Peek and Rosengren (2001).
} 
Our results show quite a contrast between the behavior of lending by foreign commercial banks and underwriting activity by foreign investment banks in Japan over our sample period. In the case of lending activity, we found that foreign bank lending was very sensitive to domestic Japanese conditions, particularly Japanese interest rates, more so than their domestic Japanese bank counterparts. In the case of underwriting activity, however, we saw marked growth in the activity over the so-called lost decade in Japan.

A key factor is these differing outcomes is likely to be the difference in borrower clienteles. The banking sector lends primarily to Japanese domestic borrowers, whose financing needs and performance are directly tied to the Japanese economy. For underwriters in the international yen-denominated sectors, the borrowers are mainly foreign firms with a specific need for yen funding or with an opportunity to swap their yen funding for another source of funding. While these borrowers would not be immune from the state of the Japanese economy and associated exchange rates, their financing needs are based on a wider set of economic and financial factors.

We should stress that our analysis for the specific Japanese case is potentially confounded by a number of other potential factors. Most notably, we have to acknowledge that the regulatory reforms that occurred in Japanese bond markets are likely to have played a large role in encouraging the increase in foreign underwriting market share in Japan in the 1990s. However, we can point to the second sharp decline in foreign bank activity, namely that subsequent to the adoption of the zero interest rate policy, as evidence that distinctions exist independent of the regulatory impact. Over this period, the reduced interest rates on Japanese loans discouraged lending by foreign banks in Japan, while the same low rates were a catalyst for bond underwriting activity 
identified with the so-called "carry trade" based on borrowing cheaply in Japan and lending abroad. 
Figure 1

\section{Foreign Bank Lending in Japan (1983-2006)}

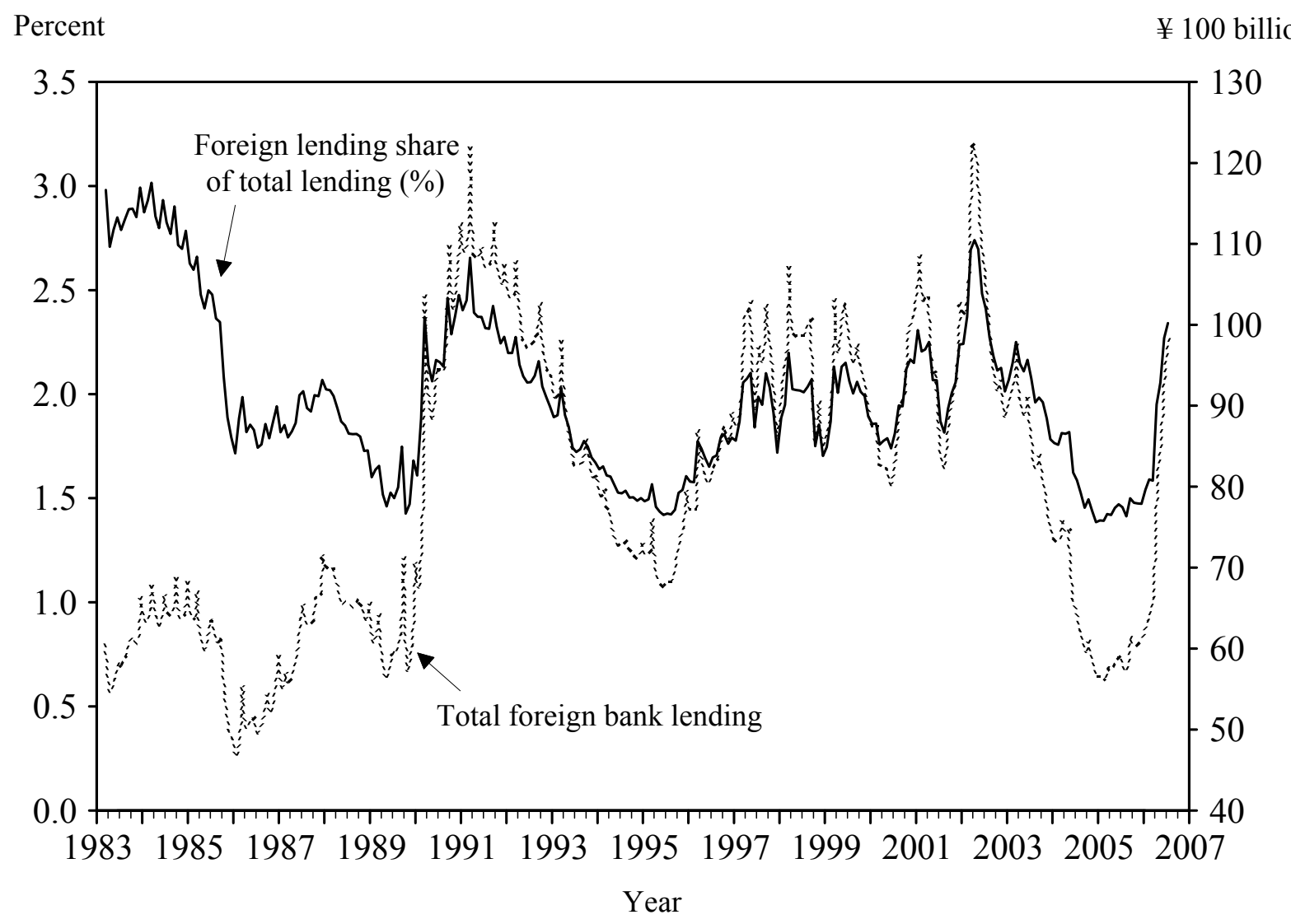

Source: Bank of Japan 
Figure 2

\section{Foreign and Domestic Bank Lending in Japan (growth 1984-2006)}

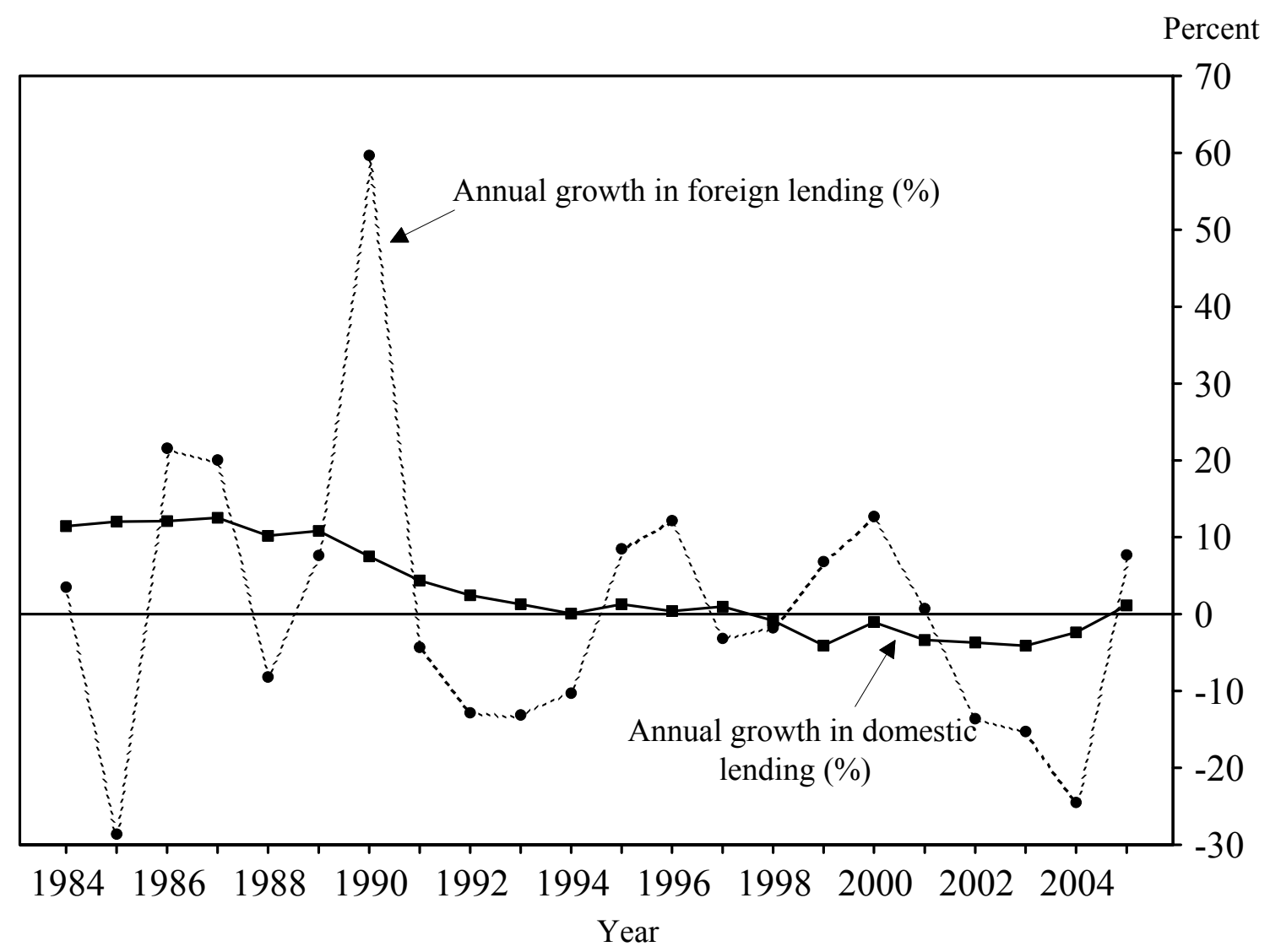

Source: Bank of Japan 


\section{Figure 3.}

\section{Issuance of international yen-denominated bonds}

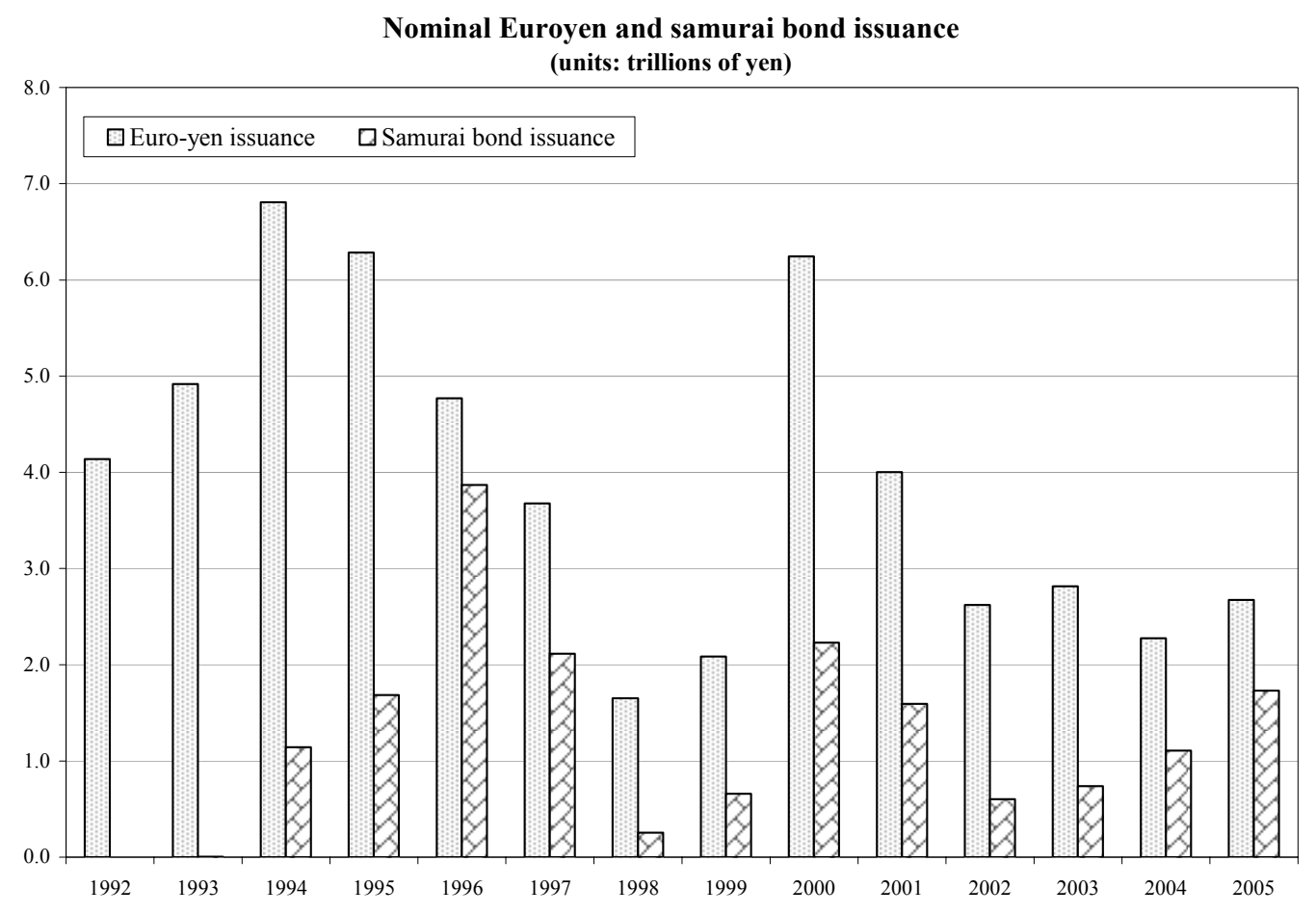

Source: Author calculations based on year-end data from the International Financing Review 


\section{Figure 4.}

\section{National shares of Samurai bond issuance}

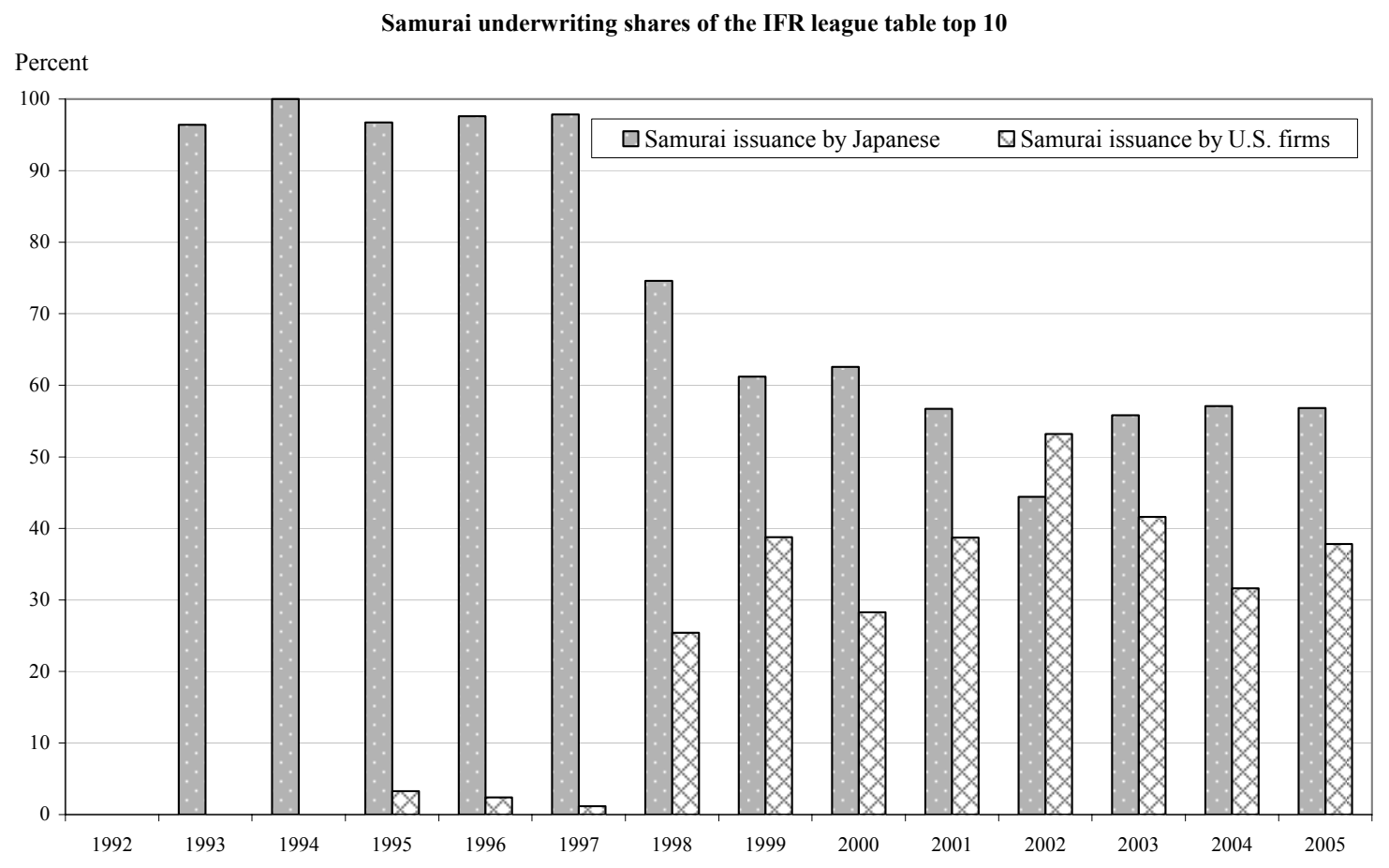

Source: Author calculations based on year-end data from the International Financing Review 


\section{Figure 5.}

\section{National shares of Euroyen bond issuance}

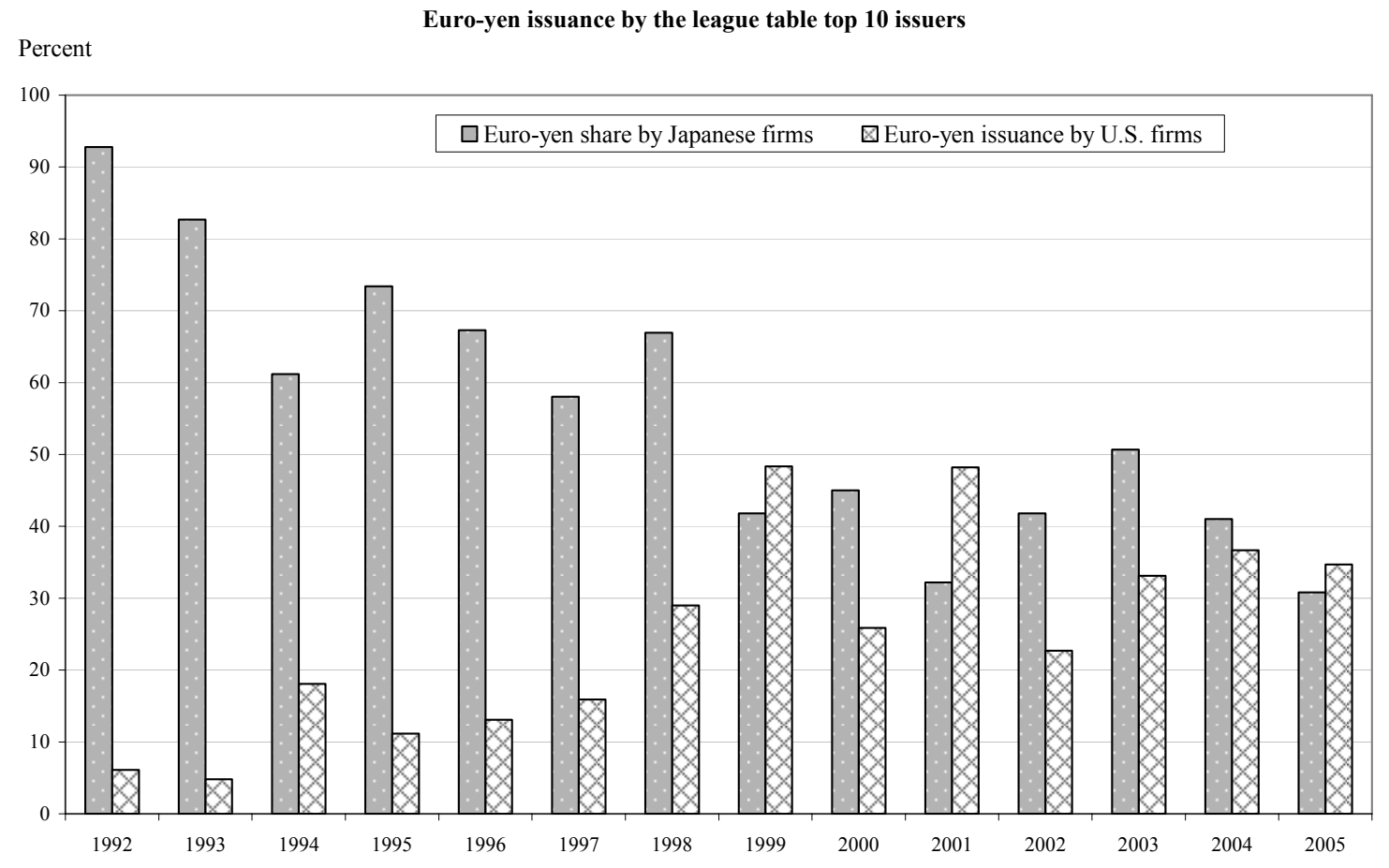

Source: Author calculations based on year-end data from the International Financing Review 


\section{Table 1}

\section{Volatility of Foreign and Domestic Lending (¥ 100 billions)}

\begin{tabular}{|c|c|c|}
\hline & Standard Deviation & Sharp Ratio $(\mu / \sigma)$ \\
\hline Foreign Lending & 18.40 & 4.43 \\
\hline Domestic Lending & 854.89 & 4.73 \\
\hline Foreign + Domestic & 866.87 & 4.76 \\
\hline $\begin{array}{l}\text { Correlation } \\
\text { Coefficient }\end{array}$ & 0.65 & \\
\hline
\end{tabular}

Source: Bank of Japan. 


\section{Table 2. \\ Determinants of foreign and domestic bank lending}

\section{Dependent Variable: Log of lending}

\begin{tabular}{|l|ll|ll|}
\hline & $\begin{array}{l}\text { Foreign } \\
\text { Banks }\end{array}$ & $\begin{array}{l}\text { Japanese } \\
\text { Banks }\end{array}$ & $\begin{array}{l}\text { Foreign } \\
\text { Banks }\end{array}$ & $\begin{array}{l}\text { Japanese } \\
\text { Banks }\end{array}$ \\
\hline Constant & $11.129^{* * *}$ & $14.897^{* * *}$ & $11.517^{* * *}$ & $15.440^{* * *}$ \\
& $(0.426)$ & $(0.255)$ & $(0.057)$ & $(0.056)$ \\
\hline Time & 0.002 & $0.003^{* *}$ & ---- & ---- \\
& $(0.003)$ & $(0.001)$ & & \\
\hline Japan 3 Month & $8.103^{* * *}$ & $6.669^{* * *}$ & $7.680^{* * *}$ & $6.077^{* * *}$ \\
Interest Rate & $(1.607)$ & $(1.008)$ & $(1.812)$ & $(1.115)$ \\
\hline US 3 Month & $-3.698^{* *}$ & -2.083 & $-4.712^{* * *}$ & $-3.501^{* * *}$ \\
Interest Rate & $(1.515)$ & $(1.373)$ & $(1.097)$ & $(1.315)$ \\
\hline GDP Growth & $-0.483^{* *}$ & $-0.197^{*}$ & $-0.566^{* * *}$ & $-0.314^{* * *}$ \\
Japan & $(0.187)$ & $(0.116)$ & $(0.182)$ & $(0.112)$ \\
\hline GDP Growth & $-0.906^{* *}$ & -0.415 & $-0.817^{*}$ & -0.291 \\
Creditor Ctys. & $(0.413)$ & $(0.320)$ & $(0.436)$ & $(0.352)$ \\
\hline Boom & $-0.181^{*}$ & $-0.337^{* * *}$ & $-0.225^{* * *}$ & $-0.399^{* * *}$ \\
& $(0.094)$ & $(0.080)$ & $(0.081)$ & $(0.081)$ \\
\hline \# of Obs. & 88 & 88 & 88 & 88 \\
\hline R-squared & 0.383 & 0.570 & 0.374 & 0.550 \\
\hline F-value & 12.24 & 19.56 & 13.31 & 22.55 \\
\hline
\end{tabular}

Note: Standard errors in parentheses. Ordinary least squares estimates with White's heteroskedasticity-corrected standard errors. GDP growth rates calculated as log differences. ${ }^{*}$ Significant at $10 \%$ confidence level. ${ }^{* *}$ Significant at $5 \%$ confidence level. $* *$ Significant at $1 \%$ confidence level. 


\section{Table 3}

\section{Determinants of changes in foreign and domestic bank lending}

Dependent Variable: difference in log of lending

\begin{tabular}{|l|ll|ll|}
\hline & $\begin{array}{l}\text { Foreign } \\
\text { Banks }\end{array}$ & $\begin{array}{l}\text { Japanese } \\
\text { Banks }\end{array}$ & $\begin{array}{l}\text { Foreign } \\
\text { Banks }\end{array}$ & $\begin{array}{l}\text { Japanese } \\
\text { Banks }\end{array}$ \\
\hline Constant & 0.004 & $0.031^{* * *}$ & -0.020 & $-0.010^{* * *}$ \\
& $(0.019)$ & $(0.006)$ & $(0.022)$ & $(0.003)$ \\
\hline$\Delta$ Japan 3 Month & $6.873^{* * *}$ & $0.977^{* *}$ & $6.486^{* * *}$ & 0.292 \\
Interest Rate & $(1.866)$ & $(0.457)$ & $(1.730)$ & $(0.340)$ \\
\hline$\Delta$ US 3 Month & $-3.501^{* * *}$ & -0.379 & $-2.950^{* *}$ & $0.596^{* * *}$ \\
Interest Rate & $(1.104)$ & $(0.463)$ & $(1.128)$ & $(0.145)$ \\
\hline$\Delta$ GDP Growth & -0.174 & -0.038 & -0.162 & -0.017 \\
Japan & $(0.245)$ & $(0.080)$ & $(0.244)$ & $(0.034)$ \\
\hline$\Delta$ GDP Growth & -0.429 & 0.023 & -0.355 & 0.152 \\
Creditor Ctys. & $(0.477)$ & $(0.153)$ & $(0.487)$ & $(0.112)$ \\
\hline Boom & ---- & --- & 0.060 & $0.107^{* * *}$ \\
& & & $(0.038)$ & $(0.006)$ \\
\hline \# of Obs. & 87 & 87 & 87 & 87 \\
\hline R-squared & 0.201 & 0.035 & 0.226 & 0.833 \\
\hline F-value & 4.46 & 1.15 & 4.59 & 104.87 \\
\hline
\end{tabular}

Standard errors in parentheses. Ordinary least squares estimates with White's heteroskedasticity-corrected standard errors. GDP growth rates calculated as log differences. * Significant at $10 \%$ confidence level. ** Significant at $5 \%$ confidence level. *** Significant at $1 \%$ confidence level. 


\section{Table 4.}

\section{Euroyen league tables for 1995 and 2005}

\begin{tabular}{|c|c|c|c|c|c|c|}
\hline \multirow[b]{2}{*}{ Rank } & \multicolumn{3}{|l|}{1995} & \multicolumn{3}{|l|}{2005} \\
\hline & Underwriter & Total ( $¥$ million: & $(\%)$ & Underwriter & Total ( $¥$ millions) & Share $(\%$ \\
\hline 1 & Nomura International & $1,181,854$ & 18.81 & Nomura & 575,843 & 21.5 \\
\hline 2 & Daiwa Europe & 941,190 & 14.98 & Citigroup & 575,117 & 21.5 \\
\hline 3 & Nikko Europe & 679,769 & 10.82 & Deutsche Bank & 368,193 & 13.8 \\
\hline 4 & IBJ International & 518,620 & 8.25 & Merrill Lynch & 163,827 & 6.1 \\
\hline 5 & Merrill Lynch & 472,699 & 7.52 & Daiwa Secs SMBC & 147,608 & 5.5 \\
\hline 6 & Yamaichi International & 412,704 & 6.57 & Barclays Capital & 147,320 & 5.5 \\
\hline 7 & Sanwa Internatioanl & 367,658 & 5.85 & Morgan Stanley & 114,608 & 4.3 \\
\hline 8 & Fuji Internatioanl & 321,942 & 5.12 & UBS & 108,526 & 4.1 \\
\hline 9 & Morgan Stanley & 228,020 & 3.63 & Mizuho FG & 101,035 & 3.8 \\
\hline 10 & Daichi Kangyo Bank & 189,524 & 3.02 & Lehman Bros & 74,905 & 2.8 \\
\hline Total & & $5,313,979$ & 84.57 & & $2,376,983$ & 88.90 \\
\hline
\end{tabular}

Source: International Financing Review 


\section{References}

Arena, M., Reinhart, C. and Vázquez, F., 2006. "The Lending Channel in Emerging Economies: Are Foreign Banks Different?," NBER Working Paper $\# 12340$.

Balder, J., Lopez, J.A. and Sweet, L.M., 1991. "Competitiveness in the Eurocredit Market," in Spindler, J.A., ed. International Competitiveness of U.S. Financial Firms: Products, Markets and Conventional Performance Measures. A Staff Study by the Federal Reserve Bank of New York. Pages 26-41.

Berger, A.N., DeYoung, R., Genay, H. and Udell, G.F., 2000. "Globalization of Financial Services: Evidence from Cross-Border Performance," Brooking Papers on Financial Performance, 2000, 23-158.

Carter, R. and Manaster, S., 1990. "Initial Public Offerings and Underwriter Reputation," Journal of Finance, 45, 1045-1068.

Claes, A., De Ceuster, M.J.K. and Polfiet, R., 2002. "Anatomy of the Eurobond Market: 1980-2000,” European Financial Management, 8, 373-386.

Claessens, S. and Glaessner, T., 1998. "Internationalization of Financial Services in Asia," Policy Research Working Paper \#1911, World Bank.

Galindo, A., Micco, A. and Powell, A., 2004. "Loyal Lenders or Fickle Financiers: Foreign Banks in Latin America," Manuscript, Inter-American Development Bank.

Goldberg, L., 2002. "When is Foreign Bank Lending to Emerging Markets Volatile?," in Edwards, S. and Frankel, J., eds. Preventing Currency Crises in Emerging Markets. NBER and University of Chicago Press, 171-198.

Goldberg, L, 2006. "The International Exposure of U.S. Banks: Europe and Latin America Compared," in Edwards, S., ed. Capital Controls and Capital Flows in Emerging Economies: Policies, Practices and Consequences. NBER and University of Chicago Press, forthcoming.

Gorton, G. and Winton, A., 2003. "Financial Intermediation," in Constantinides, G., Harris, M. and Stultz, R., eds. Handbook of the Economics of Finance, Volume 1A. Elsevier North-Holland, Chapter 8.

Hamao, Y. and Hoshi, T., 2000. "Bank-Owned Securities Subsidiaries in Japan: Evidence after the 1993 Financial System Reform," in Masohiko A. and Saxonhouse, G.R., eds. Finance, Governance and Competitiveness in Japan. Oxford University, 105-117. 
Hoschka, T.C., 2005. "Developing the Market for Local Currency Bonds by Foreign Issuers: Lessons from Asia," Working Paper Series \#63, Economics and Research Department, Asian Development Bank.

Hoshi, T. and Kashyap, A., 1999. "The Japanese Banking Crisis: Where Did it Come from and How Will it End?," in Bernanke, B.S. and Rotemberg, J., eds. NBER Macroeconomics Annual, 129-201.

Kollo, M.G., 2005. "Underwriter Competition and Gross Spreads in the Eurobond Market," Working Paper Series \#550, European Central Bank.

Kollo, M.G. and Sharpe, I.G., 2006. "Relationships and Underwriter Spreads in the Eurobond Floating Rate Market," Journal of Financial Research, 29, 163-180.

McCauley, R.N. and White, W.R., 1997. "The Euro and European Financial Markets," Working Paper \#41, Bank for International Settlements.

McCauley, R.N., 1999. "The Euro and the Liquidity of European Fixed Income Markets," in Market Liquidity: Research Findings and Selected Policy Implications. Bank for International Settlements, Committee on the Global Financial System, Publication \#11.

McKenzie, C.R. and Takaoka, S., "Underwriter Switching in the Japanese Corporate Bond Market," Manuscript, Keio University.

Megginson, W. and Weiss, K., 1991. "Venture Capitalist Certification in Initial Public Offerings," Journal of Finance, 46, 879-904.

Peek, J. and Rosengren, E.S., 1997. "The International Transmission of Financial Shocks: The Case of Japan," American Economic Review, 87, 495-505.

Peek, J. and Rosengren, E.S., 2000. "Collateral Damage: Effects of the Japanese Bank Crisis on Real Activity in the United States," American Economic Review, 90, 3045.

Peek, J. and Rosengren, E.S., 2001. "Determinants of the Japan Premium: Actions Speak Louder than Words," Journal of International Economics, 53, 283-305.

Takaoka, S. and McKenzie, C. R., 2006. "The Impact of Bank Entry in the Japanese Corporate Bond Underwriting Market," Journal of Banking and Finance, 30, 5983.

Yasuda, A., 2005. "Do Bank Relationships Affect the Firm's Underwriter Choice in the Corporate-Bond Underwriting Market?," Journal of Finance, 60, 1259-1292. 